\title{
NUTRITIONAL EVALUATION OF CORN SILAGE WITH DIFFERENT LEVELS OF INCLUSION OF WET CORN GLUTEN FEED IN SHEEP
}

\author{
AVALIAÇÃO NUTRICIONAL DE MILHO ENSILADO COM DIFERENTES NÍVEIS \\ DE INCLUSÃO DE FARELO ÚMIDO DE GLÚTEN DE MILHO EM OVINOS
}

\author{
Isis da Costa HERMISDORFF ${ }^{1}$; Isabel Cristina FERREIRA ${ }^{2}$; \\ André Madeira Silveira FRANÇA ${ }^{1}$; Tatiane Alves de MORAIS ${ }^{3}$; \\ Mayara Fabiane GONÇALVES ${ }^{1}$; Camylla Pedrosa MONTEIRO ${ }^{4}$; \\ Giovanna Faria de MORAIS ${ }^{1}$
}

1. Mestre em Ciências Veterinárias, Faculdade de Medicina Veterinária - FAMEV, Universidade Federal de Uberlândia - UFU, Uberlândia, MG, Brasil; 2. Pesquisadora A da Embrapa Cerrados e Professora Orientadora do Programa de Pós Graduação em Ciências Veterinárias - FAMEV - UFU, Uberlândia, MG, Brasil. isabel.ferreira@embrapa.br; 3. Zootecnista, FAMEV - UFU, Uberlândia, MG, Brasil; 4. Médica Veterinária, FAMEV- UFU, Uberlândia, MG, Brasil.

\begin{abstract}
The objective of this study was to evaluate the intake and apparent digestibility of nutrients, as well as the feeding behavior of sheep fed an exclusively corn silage diet $(0 \%)$; this diet incorporated wet corn gluten feed (WCGF) in increments of 30\%, 50\%, 60\%, and 90\%, together with the profile of the particles of these silages. Five crossbreed sheep were used with an average weight of $40 \mathrm{~kg}$; they were housed in metabolic cages and were arranged in a Latin square $5 \times 5$ experimental design. There was a quadratic effect on dry matter (DM) intake, with a maximum consumption of $1.75 \mathrm{~kg} / \mathrm{day}^{-1}$ to an inclusion of $39.09 \%$ of WCGF. The crude protein (CP) consumption exhibited an ascending linear effect with the inclusion of the co-product, and fiber consumption in neutral detergent fiber (NDF) and acid detergent fiber decreased linearly with the inclusion of WCGF. The apparent digestibility of DM, CP, and NDF increased linearly with the increasing inclusion of co-product in corn silage. Rumination time, total chewing, and idleness were influenced by increases in the inclusion of WCGF in corn silage, and there was a decreasing linear effect on the amount of time spent ruminating and total chewing, as well as an increasing linear effect for idleness duration. The chewing time for bolus, the number of chews for bolus, and the number of chews per day were influenced by the inclusion of WCGF. Through the obtained results, especially the equation of DM intake, which estimated a maximum point of 39.09\%, as well as the presence of diarrhea at levels up to $50 \%$, it was concluded that the addition of up to $40 \%$ of WCGF in corn silage can be recommended as it improves nutrient intake and features good digestibility without negatively altering the normal behavior of sheep.
\end{abstract}

KEYWORDS: Coproduct. Feeds. Particle size. Ruminating chew. Rumination time. Small ruminant.

\section{INTRODUCTION}

A high dependence on pastures and climatic conditions serves as the major cause of low productivity and unsatisfactory quality of ruminant production in Central Brazil. The intensification of animal production shows the need for the strategic use of conserved forage, mainly in the form of silage, for its production system, as well as to engage in better pasture management and to use coproducts from agro-industries (PEREIRA et al., 2010).

The use of co-products is an alternative method in ruminant feeding, since it has two major advantages: it decreases animals' dependence on cereals used in food, and it reduces the total cost of production (ALVES et al., 2007). Its use can be increased without harming the animal's performance (PEREIRA et al., 2010).

Wet corn gluten feed (WCGF) is a wet coproduct $(35 \%-40 \%$ dry matter $[\mathrm{DM}])$, resulting from the industrialization of corn following the extraction of germ, oil, and starch by wet processes, featuring approximately 22\%-24\% crude protein (CP), 90\% total digestible nutrients (TDN), and between 26\% and 54\% neutral detergent fiber (NDF). It is a thick concentrate, and it thus exhibits the physiological function of plant fiber and acts as a cereal grain in terms of its energy availability (SCHROEDER, 2010).

Several studies have been conducted to research the ways in which WCGF, especially regional alternatives, can be re-used in animal feed, as they are associated with low costs and favorable logistics. The effects of increasing the dietary inclusion rates $(0 \%, 11 \%, 23 \%$, and $34 \%)$ of WCGF were studied. Increasing dietary WCGF linearly increased DM intake by $11 \%$ and milk production by $8 \%$ (MULLINS et al., 2010). The physicochemical and microbiological aspects of WCGF were evaluated according to the time of ensilage. Ensiling allows for efficient conservation 
of the chemical, microbiological, and physical aspects of WCGF until of 42 days of ensilage (FRANÇA et al., 2015). For instance, Gunderson et al. (1988) evaluated lactating dairy cows that were fed a total mixed ration of WCGF. WCGF was fed at $0 \%$ (control), $10 \%, 20 \%$, and $30 \%$ of the total rationed DM. There were no significant treatment effects on DM intake, milk yield, or milk composition.

The introduction of this ingredient in animal diets has storage drawbacks due to quantitative losses that primarily occurred in response to WCGF's high moisture content and its associated environmental exposure. Moreover, when obtaining this co-product, there is a need for cost reduction; therefore, WCGF is obtained in large volumes, it is stored on the farm without the use of any technical processes, and it is stored with the aid of a plastic sheet that either covers or uncovers this co-product (FRANÇA et al., 2015).

The association of WCGF and corn silage can provide a storage alternative for WCGF over the long term, while also nutritionally enhancing the corn silage; similarly, WCGF can act as a supplement when expected crop yields are not obtained. WCGF has been used in Minas Gerais to replace both forage and concentrate in rations of dairy and beef cattle, as it is a source of highly digestible fiber, CP, and offers good cost benefits. Ensiling corn simultaneously with WCGF has a number of advantages: first, it is easy to combine with the larger corn silage particles; it ensures regional food availability when there is excess WCGF in the industry, as it can be sold at a lower price; and, finally, WCGF (with its smaller particles) may increase the packing density, while also reducing DM and spoilage losses. Food intake is influenced by both the physical structure and chemical composition of a given diet (CARVALHO et al., 2004), and feeding behavior is a very important tool in assessing the use of diets (CIRNE et al., 2014).

This study aimed to understand the effects of chemical composition, consumption, and nutrient digestibility when higher levels of WCGF are included in corn silage (particularly when compared to those levels reported in other papers) and to investigate the nutritional quality and impact caused by the use of corn silage with different levels of inclusion of WCGF in a diet for sheep.

\section{MATERIAL AND METHODS}

The experiment was conducted in the Sheep and Goats sector at the Capim Branco experimental farm of the Universidade Federal de Uberlândia (UFU) during the period spanning from June to September 2013. Five non-pregnant crossbred sheep were used, with a mean age of 40 months and an average body weight of $40 \mathrm{~kg}$; they were distributed in a $5 \times 5$ Latin square design. The animals served as experimental units to determine the apparent digestibility, DM feed intake, and feeding behavior following WCGF incorporation in their diets.

The experimental period spanned 15 days, with the first 10 days used to ensure that the animals adapted to their experimental diets, while the remaining 5 days were used to collect the data and samples. The animals were wormed and housed in individual metabolic cages with a slatted and suspended floor; they were equipped with a water dispenser, a feeder, and a trough for the supply of mineral salt. There was a device that measured the total collection of feces and urine, where feces were placed in plastic trays and urine in plastic buckets, fitted with a separator screen, so that the feces and urine did not mix.

Five different diets were used: corn silage with no WCGF added; corn silage with $30 \%$ WCGF added; corn silage with 50\% WCGF added; corn silage with $60 \%$ WCGF added; and corn silage with 90\% WCGF added. These feeds with different concentrations of WCGF were respectively weighed on a precision scale in fresh (natural) matter(characterized by its high moisture). The effects of these diets on the consumption and apparent digestibility of nutrients in sheep, on the sheep's feeding behavior, and on the silage particle profile were evaluated.

The preparation of the whole-plant corn silage was made when the grains had reached the hard-farinaceous stage. This forage was chopped into particles ranging from $1-2 \mathrm{~cm}$, with the aid of a fodder machine. The WCGF used was donated by Cargill@ Company (Uberlândia, MG, Brazil). WCGF was added in incremental amounts of 30\%, $50 \%, 60 \%$, and $90 \%$ in the silage, together with whole-plant corn, and these combinations were made in $200 \mathrm{~L}$ barrels with three replicates per treatment, totaling 15 experimental units to analyze the feed's chemical and bromatologic composition.

Throughout the entire study period, the animals received mineral salt and water ad libitum. The composition of the five experimental diets offered ad libitum twice a day ( 8 am and 4 pm) can be observed in Table 1.

Daily voluntary consumption was obtained by subtracting the amount of food left over from the amount provided; this was accomplished by weighing leftovers the next morning prior to the first 
meal of the day. Samples of the provided food and any leftovers were collected daily, placed in properly labeled plastic bags, and stored at $-20^{\circ} \mathrm{C}$ for subsequent laboratory analysis.

Table 1. Dry matter (DM), potential of hydrogen $(\mathrm{pH})$ level, crude protein $(\mathrm{CP})$, neutral detergent fiber (NDF), acid detergent fiber (ADF), ether extract (EE), total digestible nutrients (TDN), hemicellulose (HEM), and total carbohydrates (CHOT) of the experimental diets

\begin{tabular}{lccccc}
\hline & \multicolumn{6}{c}{ WCGF inclusion level $(\%)$ in corn silage } \\
Nutrients & 0 & 30 & 50 & 60 & 90 \\
\hline DM & 32.45 & 33.91 & 35.41 & 36.96 & 38.90 \\
pH & 4.13 & 4.03 & 3.96 & 4.01 & 3.78 \\
& & $(\% \mathrm{DM})$ & & & \\
$\mathrm{CP}$ & 9.38 & 13.11 & 15.05 & 16.17 & 19.44 \\
$\mathrm{NDF}$ & 56.44 & 54.86 & 52.18 & 50.92 & 46.29 \\
$\mathrm{ADF}$ & 29.20 & 24.36 & 16.74 & 15.51 & 13.80 \\
$\mathrm{EE}$ & 2.48 & 2.38 & 1.99 & 2.00 & 1.58 \\
$\mathrm{MM}$ & 6.08 & 4.38 & 5.27 & 4.26 & 4.97 \\
TDN & 67.62 & 70.81 & 75.82 & 76.63 & 77.76 \\
HEM & 27.24 & 30.50 & 35.34 & 35.14 & 32.48 \\
TCHOT & 82.04 & 80.12 & 77.68 & 77.56 & 74.00 \\
\hline
\end{tabular}

The $\mathrm{pH}$ determination and chemical analyses were performed at the Animal Nutrition Laboratory of the UFU. The $\mathrm{pH}$ value was measured with an electronic $\mathrm{pH}$ meter (MS Tecnopon®; MS Tecnopon Equipamentos Especiais, Piracicaba, Brazil), and DM was determined by means of an air circulation drying oven at $55^{\circ} \mathrm{C}$ for 72 hours. Determination of acid detergent soluble fiber (ADF), NDF, ether extract (EE), $\mathrm{CP}$, and mineral matter (MM) was performed according to the methodology suggested by the Brazilian Compendium of Animal Feeding (ANFAR, 2009). The percentage of hemicellulose was obtained by calculating the difference between NDF and ADF. The values of TDN were obtained by analyzing the diet composition using equations proposed by Kearl $(1982)(\%$ TDN $=-21.9391+1.0538 \% \mathrm{CP}+$ $0.9736 \% \mathrm{NNE}+3.0016 \% \mathrm{EE}+0.4590 \% \mathrm{CF})$. The percentage of total carbohydrates (TCHOT) was obtained by the equation from Sniffen et al. (1992): $\mathrm{TCHOT}=100-(\% \mathrm{CP}+\% \mathrm{EE}+\% \mathrm{MM})$, and the percentage of non-fiber carbohydrates (NFC) was obtained as follows: $\mathrm{CNF}=\mathrm{TCHOT}-\mathrm{NDF}$.

The apparent digestibility analysis was performed using the classic method of measuring the total feces collected (MAURÍCIO et al., 1996), and the stool samples were also placed in labeled plastic bags and stored at $-20^{\circ} \mathrm{C}$. Calculation of the coefficient of nutrient digestibility was carried out by assessing the difference between the consumed and excreted samples, according to the methodology proposed by Merchen (1988).

To determine the fecal score, the methodology proposed by Menezes de Sá et al. (2015) was followed, where the feces were assigned a score ranging from 1 to 6 , as follows: $1=$ dry and dull stools; $2=$ normal stools; $3=$ slightly loose stools; $4=$ loose stools, losing their shape but glued together; $5=$ loose stools and without normal form; and $6=$ diarrheal stools. The analysis was carried out during the 5 days of collection, at five different periods, by a person who was trained to do so.

The particle profile of silages was performed using the particle separator Penn State Particle Size ${ }^{\circledR}$ model, which contains four sieves; the sieves are separated into four different particle sizes, as follows: $>19 \mathrm{~mm}$; between $8 \mathrm{~mm}$ and 19 $\mathrm{mm}$; between $8 \mathrm{~mm}$ and $1.18 \mathrm{~mm}$; and particles $<1.18 \mathrm{~mm}$. The procedure was done according to the methodology proposed by Heinriches and Kononof (1996), and they were arranged in a randomized design.

The animals were observed on the 14th day of each trial period, and they were observed every 5 minutes over the course of 24 hours (beginning at 6 am and finishing at the same time the following day) to determine the amount of time spent feeding, ruminating, and being idle, according to the methodology proposed by Fischer et al. (1997). The observation of animal behavior was carried out by trained observers, who were strategically positioned so they would not disturb the animals. The observer was changed every 4 hours. During data collection, for night-time observation, the environment was artificially lit, and the animals were adapted to this for 3 days prior to starting this activity.

At 15th day of each trial period, the amount of time spent ruminating for each bolus (TRB; sec bolus $^{-1}$ ), the number of chews of ruminal boluses $\left(\mathrm{NCB}\right.$; number bolus ${ }^{-1}$ ), and the number of chews 
per day (NCD; number day $^{-1}$ ) were evaluated using a digital timer, according to the methodology described by Polli et al. (1996) and Burger et al. (2000).

The intake efficiencies of DM (IEDM; $g$ MS $\mathrm{h}^{-1}$ ) and NDF (IENDF; $\mathrm{g}$ NDF $\mathrm{h}^{-1}$ ) were calculated by dividing the DM and NDF consumption by feeding time (DMI/FT and NDFI/FT); rumination efficiency due to DM consumption (REDM; g DM $\mathrm{h}^{-1}$ ) and NDF (RENDF; $g$ NDF $\mathrm{h}^{-1}$ ) were calculated by assessing the relationship between the consumption of DM and NDF, according to the rumination time (h day ${ }^{-}$ ${ }^{1}$ ). The total chewing time (TCT) was given by the sum of the amount of time spent eating and ruminating.

The minimum temperature recorded was $10.9^{\circ} \mathrm{C}$ and it reached a maximum of $23.6^{\circ} \mathrm{C}$. The results fell within the range of thermal comfort $\left(10^{\circ} \mathrm{C}-25^{\circ} \mathrm{C}\right)$, indicating that the animals were not under thermal stress (EUSTÁQUIO FILHO et al., 2011).

The experimental variables were subjected to analysis of variance and regression. The significance of the regressions was obtained by the F test, adopting a 5\% probability level for type 1 errors, using the Statistical Analysis System SISVAR (FERREIRA, 2000).

\section{RESULTS AND DISCUSSION}

DM intake, expressed in $\mathrm{kg} \mathrm{day}^{-1}$, changed in association with the inclusion of WCGF in corn silage $(P<0.05)($ Table 2$)$. A quadratic effect was observed, where its maximum point was reached at $39.09 \%$ inclusion of WCGF in silage. In addition to lower consumption, those animals that consumed the silage with higher levels of WCGF (where levels of WCGF reached more than 50\%) presented with severe diarrhea (Table 2), as well as symptoms that are suggestive of subclinical acidosis, according to the Reference Advisory Group on fermentative Acidosis of Ruminants (RAGFAR, 2007). Therefore, there are indications to limit the use of WCGF at high levels, particularly when there is lower DM intake and the presence of diarrhea.

Table 2. Dry matter intake in $\mathrm{kg} \mathrm{day}^{-1}$ (DMI) and \%BW (body weight), crude protein intake (CPI), neutral detergent fiber intake (NDFI), acid detergent fiber intake (ADFI), total digestible nutrients intake (TDNI), hemicellulose intake (HEMI), non-fibrous carbohydrates intake (NFCI), total carbohydrates intake (CHOTI), and fecal score (FS) based on the levels of inclusion (Inc) of wet corn gluten feed (WCGF) in corn silage diets for sheep

\begin{tabular}{|c|c|c|c|c|c|c|c|c|}
\hline \multirow[b]{2}{*}{ Item } & \multicolumn{5}{|c|}{ Inclusion level of WCGF (\%) } & \multirow[b]{2}{*}{$\mathrm{VC}$} & \multirow[b]{2}{*}{$\mathrm{RE}^{*}$} & \multirow[b]{2}{*}{$P$} \\
\hline & 0 & 30 & 50 & 60 & 90 & & & \\
\hline DMI kg day $^{-1}$ & 1.58 & 1.74 & 1.87 & 1.60 & 1.45 & 8.53 & 1 & $P<0.0001$ \\
\hline $\mathrm{DMI} \% \mathrm{BW}$ & 3.60 & 3.68 & 3.93 & 3.51 & 3.45 & 9.78 & 2 & 0.2389 \\
\hline CPI kg day ${ }^{-1}$ & 0.11 & 0.18 & 0.22 & 0.29 & 0.40 & 27.99 & 3 & $P<0.0001$ \\
\hline NDFI kg day ${ }^{-1}$ & 0.95 & 0.82 & 0.71 & 0.68 & 0.64 & 18.44 & 4 & $P<0.0001$ \\
\hline ADFI kg day ${ }^{-1}$ & 0.49 & 0.42 & 0.28 & 0.25 & 0.22 & 17.46 & 5 & $P<0.0001$ \\
\hline TDNI kg day ${ }^{-1}$ & 1.08 & 1.20 & 1.40 & 1.22 & 1.14 & 7.26 & 6 & $P<0.0001$ \\
\hline HEMI kg day ${ }^{-1}$ & 0.43 & 0.44 & 0.42 & 0.56 & 0.58 & 0.31 & 7 & 0.4962 \\
\hline NFCI kg day ${ }^{-1}$ & 0.44 & 0.54 & 0.82 & 0.49 & 0.24 & 39.41 & 8 & $P<0.0001$ \\
\hline CHOTI kg day $^{-1}$ & 1.39 & 1.38 & 1.52 & 1.16 & 0.88 & 8.90 & 9 & $P<0.0001$ \\
\hline Fecal score & 2.00 & 2.44 & 4.32 & 5.36 & 6 & 7.6 & 10 & $P<0.0001$ \\
\hline
\end{tabular}

$\mathrm{VC}=$ variation coefficient $\mathrm{RE}=$ regression equation/mean; $P=$ probability

The ruminal $\mathrm{pH}$ of animals was not measured, but the suspected presence of subclinical acidosis can be supported by the fecal score data. By consuming silage with greater amounts of co- product $(>50 \%$ WCGF), the average fecal score obtained was 5.36, whereas those sheep fed only with corn silage had a fecal score of 2 (Table 2). The diarrhea ceased after changing the sheep's diet, 
and this did not compromise the weight of the animals. It was observed that 10 days was sufficient for the sheep to adapt to their new diet. The smaller particle size of the silage combined with the larger inclusions of WCGF (Table 5) - as well as findings in the report by Blasi et al. (2001) that described how the co-product has higher amounts of highly fermentable carbohydrates than corn silage - help reinforce this affirmation.

When expressed in $\% \mathrm{BW}$, the values for DM intake $(3.63 \% \mathrm{BW})$ were found to be above those proposed by the NRC (2007), which suggests that a consumption of DM per $1.93 \% \mathrm{BW}$ in adult sheep is required for maintenance. The difference between the data obtained and those proposed by the NRC might have resulted from differences in the weights and intake among the animals used in this trial. Also, the absence of a difference in DM intake was evident as a percentage of BW.

The CP intake increased linearly with increasing inclusion of the co-product $(P<0.05)$; there was an increase of one percentage unit WCGF in corn silage, while there was an increase of $3.2 \mathrm{~g}$ in CP intake. This result was expected, particularly since the co-product has higher amounts of CP than corn silage. Even after reducing their consumption, the animals that consumed silages with higher amounts of WCGF consumed higher levels of CP. According to the NRC (2007), for gains of $300.0 \mathrm{~g}$ $\mathrm{day}^{-1}$, sheep presenting with $20-30 \mathrm{~kg}$ of $\mathrm{BW}$ needed to consume $0.185 \mathrm{~kg} \mathrm{day}^{-1}$ of CP. From the data obtained in this study, those sheep that were fed the silages that included over $30 \%$ WCGF would have already fulfilled this requirement.
NDF and ADF intakes also changed with the increasing inclusion of WCGF in corn silage. In both cases, a decreasing linear effect was observed, where for every increase in the WCGF inclusion level, there were decreases of $3.7 \mathrm{~g}$ of $\mathrm{NDF}$ consumption, and of $3.4 \mathrm{~g}$ in ADF consumption. The decrease in NDF intake was due to the lower consumption of DM, and also to the lower levels of the latter, which was present in silages with higher inclusions of WCGF.

Likely influenced by the DMI, the consumption of TDN, NFC, and CHOT (shown in Table 2) also exhibited quadratic behavior $(P<0.05)$. The dietary TDNI was maximal $\left(1.26 \mathrm{~kg} \mathrm{day}^{-1}\right)$ for the $50 \%$ inclusion of WCGF. The NFCI was maximal $\left(0.78 \mathrm{~kg} \mathrm{day}^{-1}\right)$ for the $60 \%$ inclusion of WCGF, and the CHOTI was maximal $\left(1.47 \mathrm{~kg} \mathrm{day}^{-}\right.$ ${ }^{1}$ ) for the $30 \%$ WCGF inclusion in corn silage; from these levels upwards, there was a reduction in the consumption of these nutrients. The consumption of hemicellulose did not differ between treatments $(P>0.05)$.

The digestibility coefficients of DM (DMD), CP (CPD), and NDF (NDFD) showed significant differences $(P<0.05)$. There was a linear increase in all cases (Table 3 ). Every $1 \%$ increase of WCGF inclusion had a corresponding increase of $0.23 \%, 0.43 \%$, and $0.21 \%$ in DMD, CPD, and NDFD, respectively, which can be justified by the fact that diets with higher proportions of WCGF showed lower NDF intake, as these diets became less fibrous and lignified.

Table 3. Apparent digestibility of dry matter (DMD), apparent digestibility of neutral detergent fiber (NDFD), and apparent digestibility of crude protein (CPD) based on the levels of inclusion (Inc) of wet corn gluten feed (WCGF) in corn silage diets for sheep

\begin{tabular}{|c|c|c|c|c|c|c|c|c|}
\hline \multirow[b]{2}{*}{ Item } & \multicolumn{5}{|c|}{ Inclusion level of WCGF (\%) } & \multirow[b]{2}{*}{ VC } & \multirow[b]{2}{*}{$\mathrm{RE}^{*}$} & \multirow[b]{2}{*}{$P$} \\
\hline & 0 & 30 & 50 & 60 & 90 & & & \\
\hline DMD \% & 64.05 & 69.30 & 76.57 & 79.26 & 84.07 & 3.49 & 1 & $P<0.0001$ \\
\hline NDFD $\%$ & 56.88 & 62.87 & 68.14 & 72.68 & 74.78 & 6.67 & 2 & $P<0.0001$ \\
\hline CPD \% & 45.55 & 60.59 & 61.04 & 76.49 & 83.69 & 22.62 & 3 & $P<0.0001$ \\
\hline
\end{tabular}

$\overline{\mathrm{VC}}=$ variation coefficient $\mathrm{RE}=$ regression equation/mean; $P=$ probability

The amount of time spent feeding (Table 4) was the same among treatments $(P>0.05)$ since the time spent in idleness was altered $(P<0.05)$, according to the increase in WCGF level in corn silage; it was highest for those animals that consumed higher levels of the concentrate.
Rumination and chewing activities were lower for those animals that received higher levels of WCGF in their diets $(P<0.05)$ when compared to those that received lower levels. The most rumination activity and higher total amounts of chewing were evident among those animals that were fed a diet containing 
lower levels of WCGF, likely due to the fact that corn silage provides larger particle sizes and offers the same physical effectiveness as fiber.

According to Mertens (1997), chewing is a characteristic that reflects the physical and chemical properties of the food, such as the concentration of NDF, the particle size, and the moisture content. Therefore, when no forage fiber sources (such as WCGF) partially replace a forage, the particle size
HERMISDORFF, I. C.et al.

must be sufficient to stimulate rumination; it must also avoiding lowering the $\mathrm{pH}$ level while retaining smaller particles for longer amounts of in the rumen, which is required for fermentation. In this work, the NDF concentrations were statistically equal between treatments (Table 1), but they yielded different degrees of physical effectiveness, as evidenced by the lower rumination observed in those animals receiving higher levels of WCGF in corn silage.

Table 4. Time feeding (FT), rumination time (RT), idleness time (IT), and total chewing time (TCT) due to the levels of inclusion (Inc) of wet corn gluten feed (WCGF) in corn silage in diets

\begin{tabular}{|c|c|c|c|c|c|c|c|c|}
\hline \multirow[b]{2}{*}{$\operatorname{Item}(\%)$} & \multicolumn{5}{|c|}{ Levels of inclusion of WCGF (\%) } & \multirow[b]{2}{*}{$\mathrm{VC}$} & \multirow[b]{2}{*}{$\mathrm{RE}$} & \multirow[b]{2}{*}{$P$} \\
\hline & 0 & 30 & 50 & 60 & 90 & & & \\
\hline FT, min & 320.00 & 258.00 & 271.00 & 217.00 & 291.00 & 29.41 & 1 & 0.3602 \\
\hline $\mathrm{RT}, \min$ & 437.00 & 465.00 & 407.00 & 244.00 & 177.00 & 35.51 & 2 & $P<0.0001$ \\
\hline IT, min & 671.00 & 705.00 & 752.00 & 862.00 & 933.00 & 18.22 & 3 & $P<0.0001$ \\
\hline $\mathrm{TCT}, \min$ & 757 & 723 & 678 & 561 & 468 & 23.92 & 4 & $P<0.0001$ \\
\hline $\begin{array}{l}1 . \mathrm{FT}(\min )=27 \\
75.47 \%\end{array}$ & RT $(\min )=$ & $.703-3.2544$ & $2=73.51 \% ; 3$ & $\min )=642.3$ & $.0933 \mathrm{Inc}, R^{2}$ & $52 \% ; 4 . \mathrm{TC}$ & in) $=7$ & $37-3.6796 \mathrm{Inc}, R^{2}=$ \\
\hline
\end{tabular}

The feeding efficiencies (DMFE and NDFFE) and rumination (DMRE and NDFRE) of $\mathrm{DM}$ and NDF, expressed in $\mathrm{g}$ of DM per hour $^{-1}$ and $\mathrm{g}$ of NDF per hour ${ }^{-1}$, were not influenced $(P>0.05)$ by increasing levels of WCGF in corn silage in the diet (Table 5). The absence of the effect on feeding efficiency can be explained by the similarities observed in the feeding times. Carvalho et al. (2008), when working with Santa Ines sheep that were fed cocoa meal with the concentrate, found that feeding and rumination efficiencies (g DM and $\mathrm{NDF} \mathrm{h}{ }^{-1}$ ) were not significant. The mean values of feeding efficiency were $278.2 \mathrm{~g}$ and $119.9 \mathrm{~g}$, respectively, while those for rumination efficiency were 181.6 and $78.4 \mathrm{~g}$, respectively, for both DM and NDF fractions. Mendonça et al. (2004), when studying the behavior of dairy cows fed diets based on corn silage and sugarcane, found no significant difference between the DMRE sources of roughage.

Table 5. Feed efficiency (DM and NDF, $\mathrm{g} \mathrm{h}^{-1}$ ), rumination efficiency (DM and NDF, $\mathrm{g} \mathrm{h}^{-1}$ ), ruminating chewing time per bolus (CTB) $\left(\mathrm{sec}^{\circ}\right.$ bolus $\left.^{-1}\right)$, chews per bolus number $(\mathrm{CBN})\left(\mathrm{N}^{\circ}\right.$ bolus $\left.^{-1}\right)$, and number of chews per day $(\mathrm{CDN})\left(\mathrm{N}^{\circ}\right.$ day $\left.^{-1}\right)$ in sheep fed corn silage with different levels of inclusion (Inc) of wet corn gluten feed

\begin{tabular}{|c|c|c|c|c|c|c|c|c|}
\hline \multirow[b]{2}{*}{ Item } & \multicolumn{5}{|c|}{ Levels of inclusion of WCGF (\%) } & \multirow[b]{2}{*}{$\mathrm{VC}$} & \multirow[b]{2}{*}{$\mathrm{RE}^{*}$} & \multirow[b]{2}{*}{$P$} \\
\hline & 0 & 30 & 50 & 60 & 90 & & & \\
\hline \multicolumn{9}{|c|}{$\left(\mathrm{g} \mathrm{DM}\right.$ and $\left.\mathrm{NDF}^{-1}\right)$} \\
\hline DMFE & 325.02 & 419.06 & 415.77 & 769.61 & 314.35 & 89.95 & $\hat{Y}=448.76$ & 0.4016 \\
\hline NDFFE & 196.774 & 201.942 & 155.312 & 290.626 & 138.516 & 67.76 & $\hat{Y}=196.63$ & 0.4395 \\
\hline \multicolumn{9}{|c|}{ Rumination efficiency (g DM and $\mathrm{NDF}^{-1}$ ) } \\
\hline DMRE & 227.44 & 233.15 & 294.12 & 719.91 & 692.37 & 86.23 & $\hat{Y}=433.40$ & 0.1002 \\
\hline NDFRE & 135.84 & 116.66 & 105.53 & 299.43 & 293.84 & 82.53 & $\hat{Y}=190.264$ & 0.1436 \\
\hline \multicolumn{9}{|c|}{ Ruminating chews } \\
\hline CTB & 52.79 & 46.30 & 46.00 & 36.76 & 33.56 & 7.51 & 1 & 0.0000 \\
\hline $\mathrm{CBN}$ & 53.40 & 46.80 & 45.20 & 35.60 & 32.20 & 7.09 & 2 & 0.0000 \\
\hline $\mathrm{CDN}$ & $25,927.78$ & $27,964.91$ & $24,528.52$ & $14,835.68$ & $10,832.90$ & 35.93 & 3 & 0.0056 \\
\hline
\end{tabular}

$\mathrm{DM}=$ dry matter; $\mathrm{NDF}=$ neutral detergent fiber; $\mathrm{VC}=$ variation coefficient $\mathrm{RE}=$ regression equation $/$ mean; $P=$ probability 
Regarding the ruminating chews, the amount of time spent chewing (CTB), the number of chews per bolus (CBN), and the number of chews per day (CDN) (shown in Table 4) were significantly different $(P<0.05)$ between treatments. There was a decreasing linear effect in all cases. This behavior can be attributed to the fact that rumination decreased as WCGF levels in the animal diet increased, which is partly due to the size of the particles of the co-product.

Macedo et al. (2007) found no difference in the CTB and CBN; however, the CDN underwent a decreasing linear effect as the $\mathrm{CP}$ content increased and the NDF content fell in the animals' diet. These results are possibly associated with decreases in NDF, especially since it seems that lower daily intakes of fiber were associated with lower amounts of time spent by the animals in consumption and rumination.

When evaluating the two levels of dietary fiber in heifers, Pereira et al. (2007) reported that increasing the level of NDF in the diet from $30 \%$ to $60 \%$ increased the number of boluses ruminated per day from 28,446 to 35,105, whereas Polli et al. (1996) found that mean values of 28,710 and 30,988 were chewed per day for diets with sugarcane and corn silage, respectively.
Table 6 shows the profile of different particles in diets offered to the animals. When the percentage of particle sizes was greater than $19 \mathrm{~mm}$, ranged from $19-8 \mathrm{~mm}$, and ranged from $8-1.18$ $\mathrm{mm}$, there was a significant difference $(P<0.05)$. There was also a decreasing linear effect of the particle size of the silage with sizes larger than 19 $\mathrm{mm}$ and sizes ranging from $19-8 \mathrm{~mm}$. Since those diets containing particles with sizes between $8 \mathrm{~mm}$ and $1.18 \mathrm{~mm}$ increased linearly, particularly as the inclusion level of WCGF increased in the corn silage, the particles tended to be smaller. Those particles smaller than $1.18 \mathrm{~mm}$ were similar between treatments $(P>0.05)$.

Although the content of NDF in the WCGF was similar to that in some forage, its ability to stimulate chewing was restricted due to the small particle sizes. According to Grant (1997), when food chewing is limited, saliva production is decreased, which can lead to a decrease in ruminal $\mathrm{pH}$ and, consequently, in the fiber's overall digestibility. To minimize this effect, it is recommended that a minimum quantity of roughage be added and that proper diet particle sizes be observed, so as to reduce the rate of passage of food, stimulate chewing activity, and promote a more complete digestion of the co-products from fiber.

Table 6. Particle distribution profile (\%) of corn silage with different inclusions of WCGF

\begin{tabular}{lcccccccc}
\hline & \multicolumn{9}{c}{ Inclusion levels of WCGF $(\%)$} & & & \\
\cline { 2 - 6 } \multicolumn{1}{c}{ Particle Size $(\mathrm{mm})$} & 0 & 30 & 50 & 60 & 90 & VC & RE* & P \\
\hline$>19 \mathrm{~mm}$ & 12.28 & 11.37 & 8.91 & 8.69 & 8.63 & 21.38 & 1 & $P<0.0001$ \\
$8-19 \mathrm{~mm}$ & 50.97 & 46.11 & 50.30 & 45.26 & 38.75 & 12.41 & 2 & $P<0.0001$ \\
$1.18-8 \mathrm{~mm}$ & 29.79 & 34.87 & 33.38 & 37.83 & 48.31 & 13.15 & 3 & $P<0.0001$ \\
$<1.18 \mathrm{~mm}$ & 7.81 & 9.69 & 8.53 & 8.24 & 9.36 & 26.26 & 4 & 0.6827 \\
\hline
\end{tabular}

1. $\%>19 \mathrm{~mm}=12.115-0.00463 \mathrm{Inc}, \mathrm{R}^{2}=82.11 \% ; 2 . \% 8-19 \mathrm{~mm}=51.8008-0.1199 \mathrm{Inc}, \mathrm{R}^{2}=67.88 \% ; 3 . \% 1.18-8 \mathrm{~mm}=28.078+$ $0.1904 \mathrm{Inc}, \quad \mathrm{R}^{2}=82.73 \% ; 4 . \%<1.18 \mathrm{~mm}=8.254 ; \mathrm{C}=$ variation coefficient $\mathrm{RE}=$ regression equation $/ \mathrm{mean} ; \mathrm{P}=$ probability

Heinrichs and Kononoff (2002), using bromatological analysis, proposed that animal performance and activities are not only influenced by the chemical quality, but also by the physical quality of the bulk items used in the diet of ruminants. The proper distribution of particle sizes in bulk is important for the formulation of feed, as it establishes particle distribution in a complete diet, which correlates directly with the degree of diet selection, rumination time, the stability of ruminal $\mathrm{pH}$, the rate of passage, the degree of rumen microbial degradation, and the constancy of animal production - either meat or milk.

Through the results obtained in this investigation, especially the equation of DM intake (which reached an estimated maximum point of
$39.09 \%$ ) and the presence of diarrhea at levels as high as $50 \%$, it can be concluded that additions of up to $40 \%$ of WCGF in corn silage can be recommended, as they improve nutrient intake and provide good digestibility, without negatively altering the normal behavior of sheep. WCGF can ultimately be used as an alternative to commonly used bulk, and it may reduce the expenses associated with feeding sheep.

\section{ACKNOWLEDGEMENTS}

The authors thank the Coordenação de Aperfeiçoamento de Pessoal de Nível Superior (CAPES) for granting the scholarship, the Fundação de Amparo a Pesquisa do Estado de Minas Gerais 
(FAPEMIG) for their financial support of this work through process 01/12 CVZ APQ 00568/12, and Cargill@ for donation of the co-product.

\section{ETHICS COMMITTEE AND BIOSAFETY}

Registration and approval protocol CEUA / UFU 076/12 - Universidade Federal de Uberlandia. It is declared that at the end of the experiment, the animals were integrated into a sheep production system and they were kept on the pasture.

RESUMO: Objetivou-se com este estudo avaliar o consumo, a digestibilidade aparente dos nutrientes, e o comportamento ingestivo de ovinos alimentados com dieta exclusiva de silagem de milho (0\%), e acrescidas de 30, 50, 60 e $90 \%$ de farelo úmido de glúten de milho (FUGM), na matéria natural, juntamente com o perfil das partículas dessas silagens. Foram utilizadas cinco ovelhas sem raça definida com peso vivo médio de $40 \mathrm{~kg}$, alojadas em gaiolas metabólicas, arranjadas no delineamento experimental em quadrado latino 5x5. Houve efeito quadrático para o consumo de matéria seca, com consumo máximo de 1,75kg/dia aos 39,09\% de inclusão de FUGM. O consumo de proteína bruta sofreu efeito linear ascendente a com a inclusão do coproduto, e os consumos de fibra em detergente neutro (FDN) e fibra em detergente ácido (FDA) diminuíram linearmente com a inclusão de FUGM. A digestibilidade aparente da MS, PB e FDN aumentaram linearmente com o aumento na inclusão do coproduto na silagem de milho. Os tempos de ruminação, mastigação total, e ócio foram influenciados pelo aumento na inclusão de FUGM na silagem de milho, houve efeito linear decrescente para o tempo em ruminação, e mastigação total, e efeito linear crescente para o tempo em ócio. O tempo de mastigação por bolo, número de mastigações por bolo, e o número de mastigações por dia, sofreram influencia da inclusão de FUGM. Através dos resultados obtidos, especialmente da equação de consumo de matéria seca, que estimou ponto de máximo de $39,09 \%$ e pela presença de diarreia em animais que consumiam níveis de inclusão acima de 50\%, conclui-se que adições de até $40 \%$ de FUGM na silagem de milho são recomendadas devido ao fato do mesmo melhorar o consumo de nutrientes, tendo boa digestibilidade sem alterar negativamente o comportamento normal dos ovinos.

PALAVRAS-CHAVE: Alimentação. Coproduto. Mastigações merícicas. Pequenos ruminantes. Tamanho de partículas. Tempo de ruminação.

\section{REFERENCES}

ANFAR. Compêndio Brasileiro de Alimentação Animal - Métodos Analíticos. São Paulo, 2009. 204p.

ALVES, A. C. N.; MATTOS, W. R. S.; SANTOS, F. A. P.; LIMA, M. L. P.; PAZ, C. C. P.; PEDROSO, A. M. Substituição parcial de silagem de milho por farelo de glúten de milho desidratado na alimentação de vacas holandesas em lactação. Revista Brasileira de Zootecnia, Viçosa, v. 36, p. 1590-1596, maio. 2007.

BLASI, D. A., M. J. BROUK, J. S. DROUILLARD, AND S. P. MONTGOMERY. 2001. Corn gluten feed: Composition and feeding value for beef and dairy cattle. Kansas Coop. Ext. Svc. MF-2538. Disponível em: https://www.bookstore.ksre.ksu.edu/pubs/MF2488.pdf. Acesso em: 03 jun. 2016.

BURGER, P. J.; PEREIRA, J. C.; QUEIROZ, A. C. SILVA, J. F. C.; VALADARES FILHO, S. C.; CECON, P. R.; CASALI, A. D. P. Comportamento ingestivo em bezerros holandeses alimentados com dietas contendo diferentes níveis de concentrado. Revista Brasileira de Zootecnia, Viçosa, v. 29, p. 236-242, jan/fev. 2000.

CARVALHO, G. G. P.; PIRES, A. J. V.; SILVA, F. F.; VELOSO, C. M.; SILVA, R. R.; SILVA, H. G. O.; BONOMO, P.; MENDONÇA, S. S. Comportamento ingestivo de cabras leiteiras alimentadas com farelo de cacau ou torta de dendê. Pesquisa Agropecuária Brasileira, Brasília, v. 39, n. 9, p. 919-925, set. 2004. http://dx.doi.org/10.1590/S0100-204X2004000900012

CARVALHO, G. G. P.; PIRES, A. J. V.; SILVA, R. R.; RIBEIRO, L. S. O.; CHAGAS, D. M. T. Comportamento ingestivo de ovinos Santa Inês alimentados com dietas contendo farelo de cacau. Revista Brasileira de Zootecnia, Viçosa, v. 37, n. 4, p. 660-665, abril. 2008.

CIRNE, L. G. A.; SOBRINHO, A. G.S.; SANTANA, V. T.; SILVA, F. U.; LIMA, N. L.L.; OLIVEIRA, E. A.; CARVALHO, G. G. P.; ZEOLA, N. M. B.; TAKAHASHI, R. Comportamento ingestivo de cordeiros 
alimentados com dietas contendo feno de amoreira. Semina: Ciências Agrárias, Londrina, v. 35, n. 2, p. 10511060, mar/abr. 2014. http://dx.doi.org/10.5433/1679-0359.2014v35n2p1051

EUSTÁQUIO FILHO, A.; TEODORO, S. M., CHAVES, M. A.; SANTOS, P. F.; SILVA, M. W. R.; MURTA, R. M.; CARVALHO, G. P.; SOUZA, L. E. B. Zona de conforto térmico de ovinos da raça Santa Inês com base nas respostas fisiológicas. Revista Brasileira de Zootecnia, Viçosa, v. 40, n. 8, p. 1807-1814, dez. 2011.

FERREIRA, D. F. Análise estatísticas por meio dos Sisvar para Windows versão 4.0. In: REUNIÃO ANUAL DA REGIÃO BRASILEIRA DA SOCIEDADE INTERNACIONAL DE BIOMETRIA, 45, 2000, São Carlos, Programa e resumos. São Carlos: Universidade Federal de São Carlos, 2000. p. 255 - 258.

FISCHER, V.; DESWYSEN, A. G.; DÈSPRES, L.; DUTILLEUL, P.; LOBATO, J. F. P. Comportamento ingestivo de ovinos recebendo dieta a base de feno durante um período de seis meses. Revista Brasileira de Zootecnia, Viçosa, v. 26, n. 5, p. 1032-1038. set/out. 1997.

FRANÇA, A. M. S.; FERREIRA, I. C.; HERMISDORFF, I. C.; MENDONÇA, E. P.; FERNANDES, E. A.; ROSSI, D. A. Dinâmica química, microbiológica e física da silagem de farelo úmido de glúten de milho. Ciência Rural, Santa Maria, v. 45, n. 4, p. 684-689, 2015. http://dx.doi.org/10.1590/0103$8478 \mathrm{cr} 20140716$

GRANT, R. J. Interactions among forages and nonforage fiber sources. Journal of Dairy Science, Champagne, v. 80, p. 1438-1446, jul. 1997.

GUNDERSON, S. L; AGUILAR, A. A; JOHNSON, D. E, OLSON, J. D. Nutritional value of wet corn gluten feed for sheep and lactating dairy cows. Journal of Dairy Science. Champagne, v. 71 n. 5, p. 1204-1210. 1988.

HEINRICHS, J.; KONONOFF, P. J. Evaluating particle size of forages and TMRs using the new penn state forage particle separator. Dairy \& Animal Science, College of Agricultural Sciences - Cooperative Extension DA 2-42: Pennsylvania State University: 324 Henning Bulding, 2002.14 p. Disponível em:< www.das.psu.edu/teamdairy >Acesso em 10 jan. 2015

HEINRICHS, J.; KONONOFF, P. J. Evaluating particle size of forages and TMRs using the Penn State Particle Size Separator. Penn State, University Park, PA, 1996.

KEARL, L. C. Nutrients requirements of ruminants in developing countries. Logan: International Feedstuffs Institute, Utah Agricultural Experiment Station, Utah State University, 1982. 271 p.

MACEDO, C. A. B.; MIZUBUTI, I. Y.; MOREIRA, F. B.; PEREIRA, E. S.; RIBEIRO, E. L. A.; ROCHA, M. A.; RAMOS, B. M. O.; MORI, R. M.; PINTO, A. P.; ALVES, T. C.; CASIMIRO, T. R. Comportamento ingestivo de ovinos recebendo dietas com diferentes níveis de bagaço de laranja em substituição à silagem de sorgo na ração. Revista Brasileira de Zootecnia, Viçosa, v. 36, n. 6, p. 1910-1916, nov/dez. 2007.

MAURÍCIO, R. M.; GONÇALVES, L. C.; RESENDE, A. C; RODRIGUEZ, N. M. Determinação da digestibilidade aparente em equídeos através do óxido crômico, da lignina e da coleta total das fezes. Arquivo Brasileiro de Medicina Veterinária e Zootecnia, Belo Horizonte, v. 48, n. 6, p. 703-711, nov/dez. 1996.

MENDONÇA, S. S.; CAMPOS, J. M. S.; VALADARES FILHO, S. C. VALADARES, R. F. D.; SOARES, C. A.; LANA, R. P.; QUEIROZ, A. C.; ASSIS, A. J.; PEREIRA, M. L. A. Comportamento ingestivo de vacas leiteiras alimentadas com dietas à base de cana-de-açúcar ou silagem de milho. Revista Brasileira de Zootecnia, Viçosa, v. 33, n. 3, p. 723-728, maio/jun. 2004.

MENEZES DE SÁ, H. C.; BORGES, I.; MACEDO JUNIOR, G. L; NEIVA, J. N. M; SOUSA, L. J. Farinha do endocarpo e do babaçu na formulação de dietas para ovinos. Revista Caatinga, Mossoró, v. 28, n. 2, p. $207-$ 216, 2015. 
MERTENS, D. R. Creating a system for meeting the fiber requirements of dairy cows. Journal of Dairy Science, Champagne, v. 80, p. 1463-1481, jul. 1997.

MULLINS, C. R. ; GRIGSBY, K. N. ; ANDERSON, D. E. ; TITGEMEYER, E. C. ; BRADFORD, B. J. Effects of feeding increasing levels of wet corn gluten feed on production and ruminal fermentation in lactating dairy cows. Journal of Dairy Science, Champagne v. 93, n. 11, p. 5329-5337. 2010.

NATIONAL RESEARCH COUNCILL -NRC. Nutrient requeriments of small ruminants. Washington: National Academy Press, 2007. 362p.

PEREIRA, E. S.; PIMENTEL, P. G.; DUARTE, L. S. ; MIZUBUTI, I. Y. ; ARAÚJO, G.G. L. ; CARNEIRO, M. S. S.; REGADAS FILHO, J. G. L. ; MAIA, I. S. G. Determination of the proteins and carbohydrates fractions and estimative of the energy value of forages and by-products in Brazilian Northeast. Semina: Ciências Agrárias, Londrina, v. 31, n. 4, p. 1079-1094, out./dez. 2010. http://dx.doi.org/10.5433/16790359.2010v31n4p1079

PEREIRA, J. C. CUNHA, D. N. F. V.; CECON, P. R.; FARIA, E. S. Comportamento ingestivo e taxa de passagem de partículas em novilhas leiteiras de diferentes grupos genéticos submetidas a dietas com diferentes níveis de fibra. Revista Brasileira de Zootecnia, Viçosa, v. 36, n. 6, p. 2134-2142, nov./dez. 2007. Suplemento.

POLLI, V. A. RESTLE, J.; SENNA, D. B.; ALMEIDA, S. R. S. Aspectos relativos à ruminação de bovinos e bubalinos em regime de confinamento. Revista Brasileira de Zootecnia, Viçosa, v. 25, n. 5, p. 987-993, set/out. 1996.

RAGFAR (Reference Advisory Group on Fermentative Acidosis of Ruminants). Ruminal acidosisAetiopathogenesis, prevention and treatment. A review for veterinarians and nutritional professionals. Blackwell Publishing Asia Pty. Ltd, Carlton, VIC, Australia; 2007.

SCHROEDER, J. W. Corn gluten feed: composition, storage, handling, feeding and value, North Dakota State University, 2010. 4p. Disponível em: https://www.ag.ndsu.edu/pubs/ansci/dairy/as1127.pdf. Acesso em: 03 jun. 2016.

SNIFFEN, C. J.; O'CONNOR, D. J.; VAN SOEST, P. J.; FOX, D. G.; RUSSELL, J. B. A net carbohydrate and protein system for evaluating cattle diets: carbohydrate and protein availability. Journal of Animal Science, v. 70, n. 11, p. 3562-3577, 1992. http://dx.doi.org/10.2527/1992.70113562x 